\title{
AKTUALISASI DIRI DITINJAU DARI KUATNYA STIMULAN PADA PENYANDANG DISABALITAS DEWASA
}

\author{
Inka Anggisari \\ Fakultas Psikologi \\ Universitas Ahmad Dahlan Yogyakarta \\ inka1700013139@webmail.uad.ac.id
}

\begin{abstract}
Abstrak
Disabilitas adalah keadaan seseorang yang kurang sempurna secara psikologis, fisik, atau sensori yang berdampak pada terganggunya kemampuan untuk menjalani kegiatan seharihari. Subjek dalam penulisan ini adalah penyandang disabilitas di Sewon Bantul. Penulisan ini menggunakan metode observasi dan wawancara. Hasil menunjukkan bahwa faktor yang sangat mempengaruhi aktualisasi diri bagi penyandang disabilitas adalah stimulan atau dorangan yang kuat dari diri sendiri. Peran yayasan sendiri menyediakan lapangan pekerjaan bagi mereka yang kurang sempurna fisiknya dan telah disesuaikan dengan keterbatasan fisik sehingga menjadikan para penyandang disabilitas bisa mengaktualisasikan dirinya lewat peran yayasan yang menyediakan lapangan kerja.
\end{abstract}

Kata Kunci : disabilitas, aktualisasi diri, penerimaan diri

\section{PENDAHULUAN}

Sekian banyak ciptaan Tuhan, manusia adalah makhluk yang paling sempurna dimuka bumi ini, baik secara akal pikiran maupun bentuk fisik. Tidak ada manusia yang sama, semuanya mempunyai kelebihan dan kekurangannya masing-masing. Setiap manusia menginginkan kehidupan yang baik dan normal. Namun, seringkali terjadi hal-hal yang tidak terduga, yang menjadikan hidup mereka tidak lagi normal seperti sedia kala. Salah satunya seperti kecelakaan yang mengakibatkan kecacatan ataupun gangguan psikis.

Kata disability dalam kamus psikologi (Reber \& Reber, 2016) diartikan sebagai suatu keadaan kekurangan dalam kemampuan untuk melakukan performa sejumlah fungsi; makna lebih spesifiknya, kelemahaan bawaan atau hilangnya fungsi akibat trauma, penyakit, dsb. Somantri (2007) mengartikan disabilitas sebagai suatu keadaan rusak atau terganggu sebagai akibat gangguan bentuk atau hambatan pada tulang, otot dan sendi dalam fungsinya yang normal atau dapat diartikan sebagai suatu kondisi yang menghambat kegiatan individu sebagai akibat kerusakan atau gangguan pada tulang dan otot, sehingga mengurangi 
kapasitas normal individu untuk mengikuti pendidikan dan berdiri sendiri. Jika dilihat dari ilmu psikologi, disabilitas adalah keadaan seseorang yang kurang sempurna secara psikologis, fisikal, atau sensori yang berdampak pada terganggunya kemampuan untuk menjalani kegiatan sehari-hari.

Pemakaian kata disabilitas dirasa lebih manusiawi daripada menggunakan kata lain seperti cacat atau tidak mempunyai kemampuan. Maka dengan menggunakan kata disabilitas bisa lebih memperhalus makna dan merubah persepsi masyarakat akan penyandang disabilitas yang sering di pandang sebelah mata karena dirasa hanya akan membebani orang lain dalam segala aktifitas. Pemahaman ini diharapkan masyarakat lebih bisa menghargai seorang penyandang disabilitas bahwa mereka juga bagian dari makhluk Tuhan yang berbeda kondisi fisiknya, tetapi mempunyai hak asasi yang sama untuk melangsungkan hidup.

Berdasarkan hasil wawancara dengan penyandang disabilitas di Sewon Bantul, menyatakan bahwa persoalan mendasar para penyandang disabilitas untuk mencapai aktualisasi diri terletak pada bagaimana cara memandang diri sendiri. Penyandang disabilitas yang hanya memikirkan kecacatan dan kekurangannya saja akan memandang dirinya sendiri sebagai individu yang tidak berarti dan hanya mempunyai citra diri yang negatif. Tentama (2011) mengatakan bahwa individu penyandang disabilitas yang memiliki perasaan inferioritas dapat menimbulkan permasalahan pada penerimaan diri individu. Tentu hal tersebut sangat mempengaruhi dalam mencapai bentuk aktualisasi diri. Dengan demikian, individu diharapkan mampu untuk introspeksi diri agar menyadari bahwa hidup tidak hanya diperuntukkan bagi orang-orang yang sempurna bentuk fisiknya, yang cacat fisiknya pun memiliki keunikan tersendiri apabila menyadari potensi yang dimiliki. Kemampuan-kemampuan yang dimiliki, dengan segala keterbatasan fisik, adanya stimulan yang kuat akan membuat individu berusaha mengaktualisasikan dirinya. Selain itu diperlukannya individu untuk mampu berpikir positif, seperti yang dikemukakan oleh Tentama (2012) bahwa individu yang mampu berpikir positif bisa dengan mudah menerima keadaan dirinya. Berpikir positif menjadi sangat berharga dan penting bagi penyandang disabilitas karena berpikirpositif dapat membuat individu memusatkan perhatian pada halhal positif dari berbagai permasalahan yang dihadapi difabel sehingga difabel dapat merasa 
tenang, rileks, dan dapat menyesuaikan dirinya untuk mengatasi masalah yang dihadapi (Tentama, 2014, 2010). Corey (dalam Hanifah, 2005) menyatakan bahwa manusia berjuang untuk mengaktualisasikan dirinya yakni kecenderungan menjadi apa saja yang individu mampu. Aktualisasi diri merupakan sarana menuangkan diri dalam kapasitas individu sebagai manusia yang menuntut direalisasikannya semua potensi serta bakat yang sesuai dengan kemampuan, minat dan bidangnya masing-masing.

Adanya kebutuhan aktualisasi diri yang cukup besar karena sudah ada tanggungan seperti keluarga yang mengharuskan individu untuk mencukupi kebutuhan hidup, menjadikan berpacunya semangat untuk lebih menggali dan mengembangkan segenap potensi, serta kemampuan yang dimiliki. Selain keluarga sebagai salah satu faktor pendorong, lingkungan masyarakat turut menjadi cambuk semangat, dimana seorang penyandang disabilitas ingin diakui bahwa dengan keterbatasan fisiknya, individu mampu mencapai target hidup seperti yang orang normal lain raih. Pengaruh-pengaruh yang mengharuskan individu untuk bertindak lebih baik bisa menjadi sebuah motivasi yang positif bagi individu. Tentama (2016) mengemukakan bahwa motivasi yang positif akan mendorong individu untuk mencapai aktualisasi diri, dengan begitu individu dapat mengaktualisasi diri dengan baik.

\section{PEMBAHASAN}

Aktualisasi diri adalah segala sesuatu yang mendorong seseorang untuk menjadi yang terbaik yang bisa dilakukan. Rogers (dalam Schultz, 1993) menyatakan bahwa tiap orang memiliki kecenderungan akan kebutuhan aktualisasi diri untuk mengembangkan seluruh potensinya. Kecenderungan akan kebutuhan aktualisasi diri juga dimiliki oleh penyandang cacat sebagai tenaga pendorong untuk meningkatkan pematangan dan pertumbuhan fisiologis maupun psikologis.

\section{A. Aspek-aspek aktualisasi diri}

Vallet (dalam Hanifah, 2005) berpendapat bahwa aspek-aspek proses perkembangan seseorang untuk mewujudkan aktualisasi dirinya, antara lain:

a. Memahami kebutuhan dasar yang manusiawi, yaitu bagaimana individu memahami kebutuhan-kebutuhannya yang paling mendasar. 
b. Mengungkapkan perasaan yang manusiawi, yaitu ungkapan-ungkapan individu tentang apa yang dirasakannya.

c. Kesadaran dan kontrol diri, bagaimana individu mampu menyadari dan mengontrol setiap tindakannya sehingga sesuai dengan harapan-harapannya.

d. Menjadi sadar akan nilai-nilai manusiawi, kemampuan individu untuk bisa menerima nilai-nilai yang berlaku di sekelilingnya, seperti bekerja sama dengan orang lain.

e. Mengembangkan kedewasaan sosial dan individu, kemampuan individu untuk dapat mempertimbangkan segala tindakan yang dilakukan serta mampu menyesuaikan diri dengan lingkungan sosialnya.

B. Faktor-faktor aktualisasi diri

Anari (dalam Hanifah, 2005) menyebutkan bahwa factor-faktor yang mempengaruhi aktualisasi diri adalah:

a. Kreativitas, merupakan sikap yang diharapkan ada pada orang yang beraktualisasi diri. Kreativitas bagi mereka adalah suatu sikap. Individu ini asli, inventif dan inovatif meski tidak harus menghasilkan sesuatu.

b. Kepribadian, yaitu organisasi yang dinamis dalam diri individu yang terdiri dari sistem-sistem psiko-fisik yang menentukan cara penyesuaian diri yang unik (khusus) dari individu terhadap lingkungan.

c. Transendensi, yaitu lebih tinggi, unggul, agung, melampaui superlatif arti yang lain tidak tergantung dan tersendiri. Individu yang beraktualisasi diri akan berusaha menjadi yang terbaik.

d. Demokratis, orang yang beraktualisasi diri bertingkah laku lebih dalam daripada toleransi. Meski individu menyadari bahwa perbedaan-perbedaan dengan orang lain, tetapi individu dapat menerima semua orang tanpa memperhatikan tingkat pendidikan dan kelas sosial. Individu siap mendengarkan dan belajar pada siapa saja yang dapat mengajarkan itu pada dirinya.

e. Hubungan sosial, yaitu individu akan lebih menghargai keberadaan orang lain dalam lingkungannya. 
Berdasarkan hasil observasi pada penyandang disabilitas di yayasan penyandang cacat mandiri sewon bantul, subjek yang bernama bapak Rusdi Musono (30 tahun) cacat akibat kecelakaan motor yang menjadikan tangan kanannya kehilangan fungsi semestinya membuat kehidupan yang dahulunya normal menjadi berbanding terbalik karena hal tersebut. Gairah untuk hidup pun tidak lagi ada karena keterbatasan fisik yang dirasa tidak ada gunanya. Hingga suatu hari timbul sebuah dorongan dari diri sendiri untuk bangkit dari keterpurukan, untuk melanjutkan hidup dengan fisik yang seadanya.

Rogers (dalam Martosudarmo, 2005) menyatakan bahwa pada hakikatnya manusia mempunyai potensi untuk tumbuh dan berkembang ke arah yang lebih baik jika kondisi memungkinkan. Dengan berada pada tempat yang benar dan bersama orang-orang yang senasib, menjadikan subjek dapat berinteraksi dan bersosialisasi dengan mudah. Adanya tanggungan keluarga yang harus dicukupi kebutuhanya, membuat subjek semakin bersemangat dalam bekerja mencukupi kebutuhan hidup.

Maslow (1994) menyatakan bahwa tingkatan terakhir dari kebutuhan dasar adalah aktualisasi diri, yaitu kebutuhan untuk membuktikan dan menunjukan dirinya kepada orang lain.Pada tahap ini, seseorang mengembangkan semaksimal mungkin segala potensi yang dimilikinya. Kebutuhan aktualisasi diri adalah kebutuhan yang tidak melibatkan keseimbangan, tetapi melibatkan keinginan yang terus menerus untuk memenuhi potensi. Maslow melukiskan kebutuhan ini sebagai hasrat untuk semakin menjadi diri sepenuh kemampuannya sendiri, menjadi apa saja menurut kemampuannya. Terpenuhinya kebutuhan-kebutuhan sebelumnya seperti kebutuhan fisiologis, rasa aman, kasih sayang, dan harga diri telah mengantarkan akan terpenuhinya kebutuhan akan aktualisasi diri. Keadaan saat seorang individu ingin membuktikan bahwa dirinya layak untuk diakui seperti yang lain. Bentuk akualisasi diri yang telah dicapai oleh subjek terlihat dari sejak tumbuhnya motivasi yang kuat untuk melanjutkan hidup meskipun dengan keterbatasan fisik. Bertahan dari lingkup masyarakat yang cenderung menatap belas kasihan. Kemudian dengan adanya yayasan yang dikhususkan sebagai wadah bagi penyandang disabilitas untuk berkarir, menjadikan subjek dapat menuangkan segenap potensi yang subjek miliki dengan pekerjaan yang telah diberikan dan telah disesuaikan. Mendapat pekerjaan yang layak untuk mencukupi kebutuhan keluarga dan mampu hidup dengan layak dari hasil kerja 
kerasnya sendiri telah dapat membuktikan kepada masyarakat bahwa penyandang disabilitas tidak hidup hanya bertumpu kepada orang lain, yakni bisa mandiri layaknya orang normal dan dapat mencapai kebutuhan-kebutuhan tertinggi dengan upaya dan semangat hidup yang tinggi.

\section{KESIMPULAN}

Motivasi terbesar timbul dari dalam diri sendiri. Kemauan akan hidup yang lebih baik akan terealisasikan dengan mudah jika terdapat stimulan yang kuat, tidak memandang apakah seseorang itu sempurna fisiknya ataupun sebaliknya. Dilihat dari subjek penyandang disabilitas tersebut, kebutuhan mencapai proses aktualisasi diri tidaklah mudah dan cepat. Mengemban tanggung jawab sebagai tulang punggung keluarga, mengharuskan subjek untuk mencukupi kebutuhan hidup. Akibat dari adanya stimulan yang kuat dalam kondisi-kondisi tersebut, menjadikan subjek dapat membawa dirinya mencapai pada tingkat kebutuhan tertinggi, yakni dapat beraktualisasi diri. 


\section{DAFTAR PUSTAKA}

Hanifah. (2005). Hubungan dukungan sosial dan kecenderungan berpikir positif dengan aktualisasi diri pada siswa-siswi smplb bagian tuna daksa. Jurnal Psikologi, 2(1), 95-160.

Maslow, A. (1994). Motivasi dan kepribadian (teori motivasi dengan pendekatan hierarki kebutuhan manusia). Jakarta : PT. PBP.

Martosudarmo. (2005). Hubungan antara aktualisasi diri dengan intensi melakukan kompetisi kerja. Jurnal Psikologi, 1(1), 300-395.

Pranungsari, D., Tentama, F., \& Tarnoto, N. (2016). Achievement motivation training (AMT) sebagai upaya mencegah kenakalan remaja. Prosiding Seminar Nasional Hasil Pengabdian kepada Masyarakat. Yogyakarta. ISBN 978-602-229-683-6.

Reber, A. S. \& Reber, E. S. (2016). Kamus psikologi. Yogyakarta: Pusataka Pelajar.

Schultz. (1993). Psikologi pertumbuhan model-model kepribadian sehat. (terjemahan yustinus ). Yogyakarta: Penerbit Kanisius.

Somantri, S. (2006). Psikologi anak luar biasa. Bandung: PT. Refika Aditama.

Tentama, F. (2010). Berpikir positif dan penerimaan diri pada remaja penyandang cacat tubuh akibat kecelakaan. Humanitas VII(1), 66-75.

Tentama, F. (2011). Hubungan inferioritas dengan self-acceptance pada penyandang tuna daksa. Prosiding Seminar Nasional Hasil Penelitian Dosen Kopertis Wilayah V. Yogyakarta: Kopertis V. ISBN: 978-602-9367-04-1.

Tentama, F. (2012). Membangkitkan pikiran positif difabel. Republika, 76.

Tentama, F. (2014) Hubungan positive thinking dengan self-acceptance pada difabel (bawaan lahir) di SLB negeri 3 Yogyakarta. Jurnal psikologi integratif, 2(2), 1-7. 